\title{
Innovation Development Strategy for Enterprises of the Tatarstan Republic
}

\author{
Kodolova I. A. ${ }^{1}$, Stepanova Yu. V. ${ }^{1} \&$ Arzhantseva N. V. ${ }^{2}$ \\ ${ }^{1}$ Kazan Federal University, Institute of Management, Economics and Finance, Kazan, Russia \\ ${ }^{2}$ Kazan Federal University, Institute of Language, Kazan, Russia \\ Correspondence: Kodolova I. A., Kazan Federal University, Institute of Management, Economics and Finance, \\ Kazan, 420008, Russia.
}

Received: March 19, 2015 Accepted: March 31, 2015 Online Published: April 30, 2015

doi:10.5539/ass.v11n11p323 URL: http://dx.doi.org/10.5539/ass.v11n11p323

\begin{abstract}
The article deals with the issues of Tatarstan enterprises' changeover to the innovative model of development. The authors describe the dynamics of innovation processes in Tatarstan on the basis of introduction of advanced technologies, analyze innovation activity indicators of enterprises for the recent ten years and classify innovatively-active enterprises according to the types of economic activity. The authors also give a detailed analysis of changes in the input costs pattern for innovation production manufacturing at the enterprises of Tatarstan, assess the dynamics of innovation production shipment by the enterprises for the recent five years. The authors provide some comparative data of the Tatarstan Republic and the regions of Volga Federal District and also provide some managerial recommendations on stimulating the innovation activities on the regional level.
\end{abstract}

Keywords: innovation development strategy, innovation activities, innovation potential, innovativeness of enterprises, innovative costs, innovation activities in the regions of Volga Federal District

\section{Introduction}

The strategic goal of Russian economic development lies in the sphere of changeover to an innovative model of development. The formation of a national innovation system and creation of innovation infrastructure which would provide technological economic modernization, rise of its competitiveness on the basis of advanced technologies and transformation of scientific potential into one of major resources for a steady economic growth are set as the main tasks in the governmental programme decisions (RF Governmental Decree from 8 2011).

At present the innovation sphere is undergoing significant changes. However, there are some problems in the sphere of Russian economy: low demand for innovations, low level of innovation activities at enterprises, and also ineffective innovation structure. World practice shows that for effective transition of Russian economy to innovative development it is necessary to implement radical restructuring, development of power-efficient and other advanced technologies, substantial increase of investments into the innovation sphere. Recently, $75 \%$ of GDP growth in developed countries of the world is formed due to innovations. Their share in the European Union constitutes more that $50 \%$ (Gretchenko, 2011, p. 16). While the proportion of innovatively-active enterprises in Russia makes less than $10 \%$.

Modern conditions of development of Russian regions contribute greatly to innovation development of economic entities. Regional innovative potential is understood as a sum of apparent resources and unimproved opportunities and also conditions which influence the economic entity activity and form its readiness, necessity and ability to effectively act in the field of innovations. The Tatarstan Republic occupies the $5^{\text {th }}$ place among the regions of Russia with the highest innovation potential and shows high indexes in two components relevant for innovation potential: scientific-and-technological and infrastructural (Makarova, 2011, p. 48)

Revitalization of innovation activity on the regional level is a strategic task for economic development of the Tatarstan Republic. Innovation processes management on the regional level appeals to a clear understanding of objective laws, problems and specific features of innovation activity. The development strategy of Volga Federal District worked out for the period up to 2020 envisages the necessity to strengthen the role of innovations in social and economic development of the region as one of the leading mechanisms in order to pursue the strategic objectives (RF Governmental Edict 7.2.2011). 
In this respect we assume it as topical to investigate the strategy of innovation development and innovation activity of the region by examining the example of the Tatarstan Republic having set the goal of the investigation to explore the main problems of innovation growth of the region, its opportunities and advantages. Being the document which modifies the mechanisms and major macroeconomic indexes of the realization of the innovation development strategy of the Tatarstan Republic for the mid-term prospects, Innovation Memorandum accepted in 2011 sets the major priorities of innovation activity and priority types of innovation products directed to create technological systems of contemporary and newest technological mode for the Tatarstan Republic (Cabinet of Ministers' Decree, 24.01.2011).

Carrying out a detailed analysis of the innovation activity indexes is estimated as necessary in order to provide coordinated operation of innovation activity entities, to increase the efficiency of state regulation of the innovation sphere in the region and achieve its main objectives. The assessment of the dynamics of innovation activity of regional enterprises reveals the annual increase in the number of innovatively-active enterprises in 2003-2012. There has been a steady growth in the level of innovation activity of enterprises in the Republic of Tatarstan within the last decade; it grew from $12.7 \%$ in 2003 to $19.1 \%$ in 2012, table 1.

Innovation activity was characteristic for 164 organizations in Tatarstan Republic in 2012, in other words, 19.1\% of all examined organizations, Figure 1.

Table 1. Level of innovation activity at the enterprises of Tatarstan Republic (percentage)

\begin{tabular}{|c|c|c|c|c|c|c|c|c|c|c|}
\hline & 2003 & 2004 & 2005 & 2006 & 2007 & 2008 & 2009 & 2010 & 2011 & 2012 \\
\hline $\begin{array}{l}\text { Proportion of organizations } \\
\text { engaged in innovation activity in } \\
\text { the total number of examined } \\
\text { organizations }\end{array}$ & 12,7 & 15,9 & 12,7 & 12,8 & 14,1 & 14,3 & 14,5 & 14,9 & 18,1 & 19,1 \\
\hline $\begin{array}{c}\text { Proportion of innovation } \\
\text { production in the total volume of } \\
\text { production shipped by } \\
\text { innovatively-active enterprises }\end{array}$ & 12,0 & 15,0 & 32,1 & 27,9 & 23,5 & 22,9 & 25,2 & 21,2 & 20,2 & 18,4 \\
\hline
\end{tabular}

The general tendency of innovation processes in the Republic is determined by industrial enterprises marked by a higher level of innovative activity than on average in Tatarstan. The share of industrial enterprises in 2012 is $72 \%$ of all innovatively-active organizations $(87.7 \%$ in 2008) (Tatarstan department of Federal State Statistics Service, 2013).

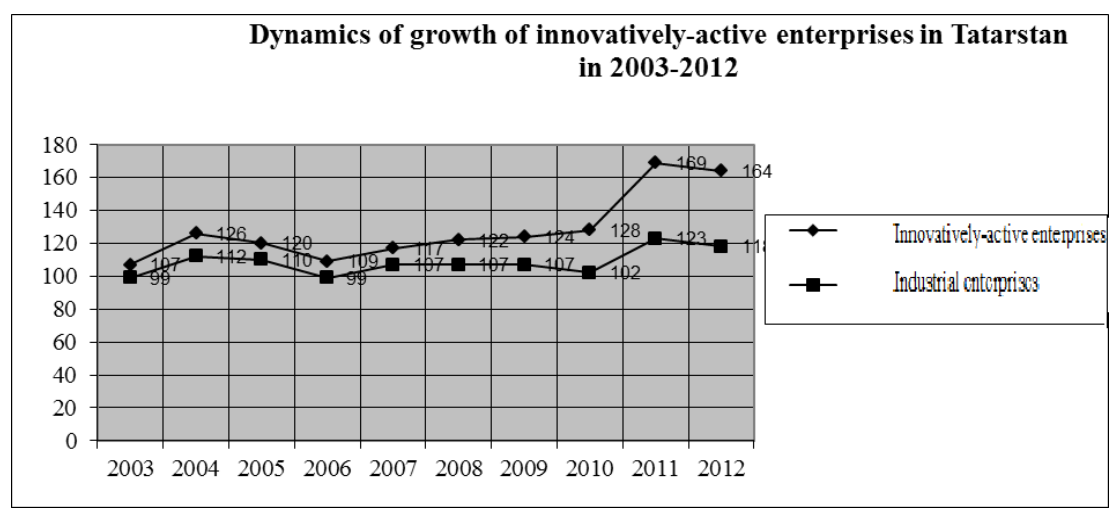

Figure 1. Dynamics of growth of innovatively-active enterprises in Tatarstan

Major share of the shipped innovation activity belongs to industrial enterprises, which made $98.8 \%$ of all enterprises shipping innovative goods in 2012 (98.96\% - in 2008). In general, these are large enterprises of oil extraction and processing, chemical, food industry, car industry, having big industrial opportunities and a high share of added value of shipped innovation production in the total shipment volume.

The analysis of the activity of the enterprises of Tatarstan Republic shows that innovative processes are actively embedded at such organizations of economic activities as scientific researches and projects (14\%), electric, electronic and optical equipment manufacturing (10.4\%), food products manufacturing $(8.5 \%)$, chemical 
industry (7.9\%), transport means and equipment production (7.9\%), fuel-and-energy resources extraction (7.6\%), electricity, gas and water production and distribution (5.5\%), Figure 2.

Quite a low level of innovation activity was noticed at the enterprises of leather, leather goods and footwear manufacturing $(0.6 \%)$, wood processing and wooden products manufacturing $(0.6 \%)$, coke, oil products and nuclear material production $(1.2 \%)$, at the enterprises of textile and clothing manufacture $(1.8 \%)$ in the year of 2012.

In the period from 2008 to 2012 there were noticed remarkable changes in the innovation product production costs, Table 2. The enterprises of the Republic spent more than 25 billion rubles a year in the pre-crisis period. The cost volume of 2009 constituted 8.2 bln rubles, which is $64.8 \%$ lower compared to the level of 2008 . A sharp decrease of total innovation costs is strongly connected with the complicated conditions on the Russian and international markets and with the necessity to satisfy current payment obligations.

\section{Innovation activities of Tatarstan enterprises according to the types of economic activity in $\mathbf{2 0 1 2}$}
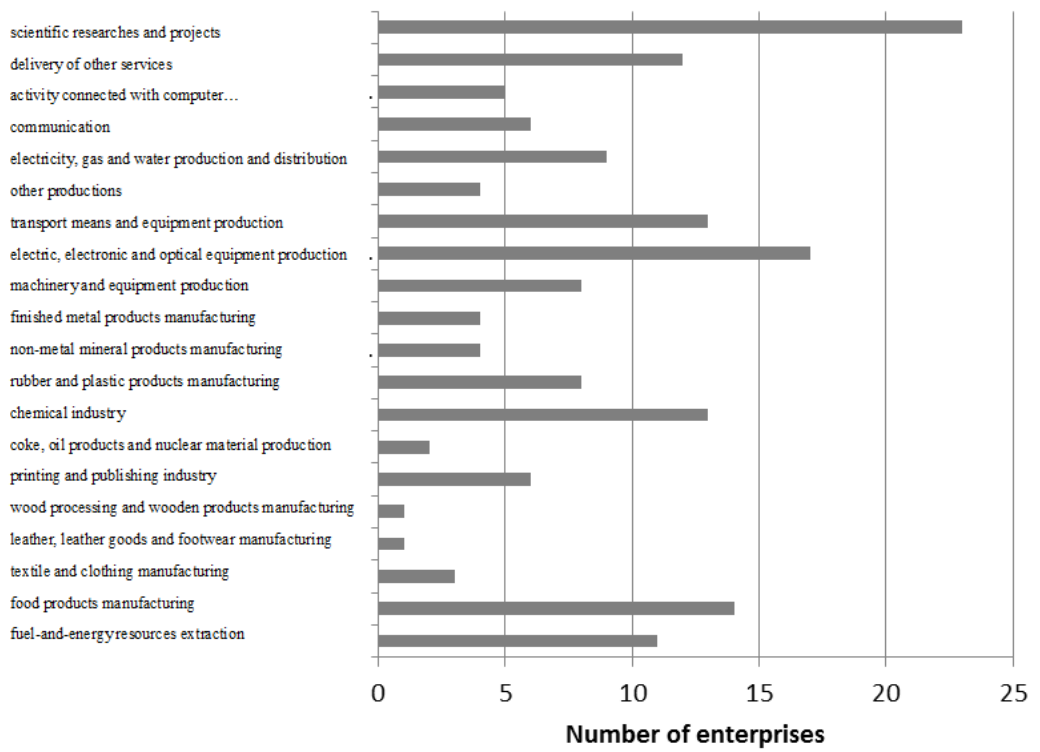

Figure 2. Innovation activities of Tatarstan enterprises according to the types of economic activity in 2012

A significant increase in total expenditures for innovations took place in 2011 and constituted 44.4 bln rubles, $186 \%$ increase compared to 2008. Innovation expenditures decreased in 2012 and constituted 38.3 bln rubles (Tatarstan department of Federal State Statistics Service, 2013).

Table 2. Expenditures of organizations for innovations

\begin{tabular}{llllll}
\hline Indicators & 2008 & 2009 & 2010 & 2011 & 2012 \\
\hline $\begin{array}{l}\text { Expenditures for innovations, mln rubles } \\
\text { including }\end{array}$ & 23806,3 & 8432,3 & 14626,1 & 44424,8 & 38238,0 \\
-technological innovations & & & & & \\
-marketing innovations & 23731,3 & 8262,5 & 14351,1 & 44166,4 & 38101,0 \\
-organizational innovations & 32,2 & 42,8 & 112,9 & 26,6 & 62,9 \\
\hline
\end{tabular}

The level of innovation activity at the enterprises practicing technological innovations constituted $16.9 \%$ in 2012 (12.8\% - in 2008). Total expenditures for innovations in the Republic increased more than twice during 3 years and constituted $38101 \mathrm{mln}$ rubles. The biggest part of expenditures (57\%) for technological innovations is spent to acquire machinery and equipment for technological innovations, Figure 3. Although the given index increased greatly from $38 \%$ in 2010 to $57 \%$ in 2012 , the given process is not enough to assert that a complex modernization of all industrial activity in the Republic has started. 


\section{Expenditures for technological innovations according to types of} innovation activity in 2012
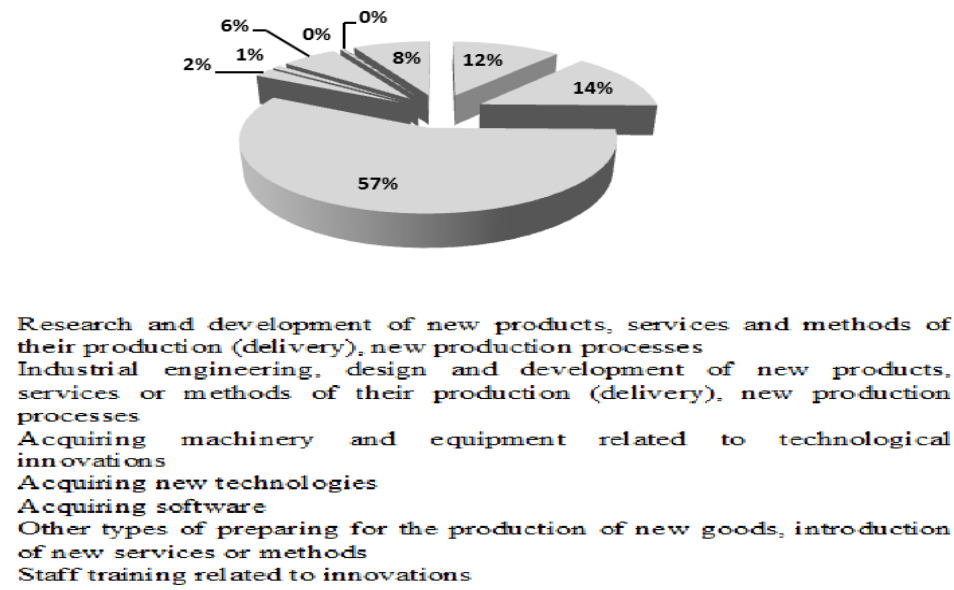

Figure 3. Expenditures for technological innovations according to the type of innovation activity in 2012

Expenditures of enterprises for industrial development, design and new projects, services or methods of their production, new operating processes occupy the second place in volumes and comprise $14 \%$ in 2012. During the last 3 years this indicator has grown sixfold.

Expenditures for researches and development of new products, services and methods of their production, new operating processes in the structure of expenditures for technological innovations occupy the third place in volume, but there is a big gap between the ones mentioned above and the expenditures for purchasing machinery and equipment, and they constitute $12 \%$ in 2012. This indicator was significantly higher in $2010-18.7 \%$. Driving down the costs for research and development of new products and also services and methods of their production as well as new operating processes has a negative influence on the innovation process.

Expenditures connected with the innovation products operations constitute an insignificant part of expenditures: purchasing new technologies $-2.1 \%$, purchasing programming tools $-0.9 \%$. It should be noted that during the period of $2010-2012$ there was a significant reduction in expenditure for acquiring new technologies - more than 1.5 times. An absolutely insignificant part of expenditure for innovations is directed towards the staff training connected with innovations $(0.4 \%)$ and expenditures for marketing research $(0.07 \%)$.

During several years a significant role has been attributed to organizational and marketing innovations, because the transition to innovative development means that innovations should include not only development of new technologies, their application in manufacture, but also promotional support and effective info-communicational infrastructure. However, such innovations are not widely spread at enterprises, which prevents innovation activity.

In the conditions of high competition a big role in the success of domestic enterprises is attributed to the promotion of product innovation. The most effective strategy in the development of product innovations at Tatarstan enterprises may become a technologically complicated knowledge-intensive product release based on the usage of several established but a bit improved components. According to Tatarstan State Statistics Service among all industrial expenditures for innovation activity in $201186.5 \%$ were the expenditures for product innovations and $13.5 \%$ - expenditures for operating innovations (Tatarstan department of Federal State Statistics Service, 2013). The share of expenditures for operating innovations increased significantly and constituted $44.2 \%$ in 2012. Among all types of economic activity the biggest share of expenditures for operating innovations belongs to chemical industry $-21.9 \%$, transport means and equipment production $-8.1 \%$, fuel-and-energy resources extraction - 7\%, Figure 4.

Expenditures for product innovations constituted 55.8\% in 2012, the biggest share of them was marked at the enterprises of coke, oil products and nuclear material production $-28 \%$, transport means and equipment production $-12 \%$, chemical industry enterprises $-11.3 \%$.

Eventual result of innovation activity is the promotion of more effective types of technologies, raw materials and materials, development and improvement of the existing products. Tatarstan enterprises and organizations produced innovation goods, works and services for $272573.9 \mathrm{mln}$ roubles in 2012 . Industrial enterprises 
shipped innovative goods, works and services for 2696306.4 mln rubles or $18.4 \%$ of the general volume of the production shipped by innovatively-active enterprises, Table 3 .

\section{Expenaıtures of Inqustrial enterprises of Tatarstan according to the type of innovations 2012}

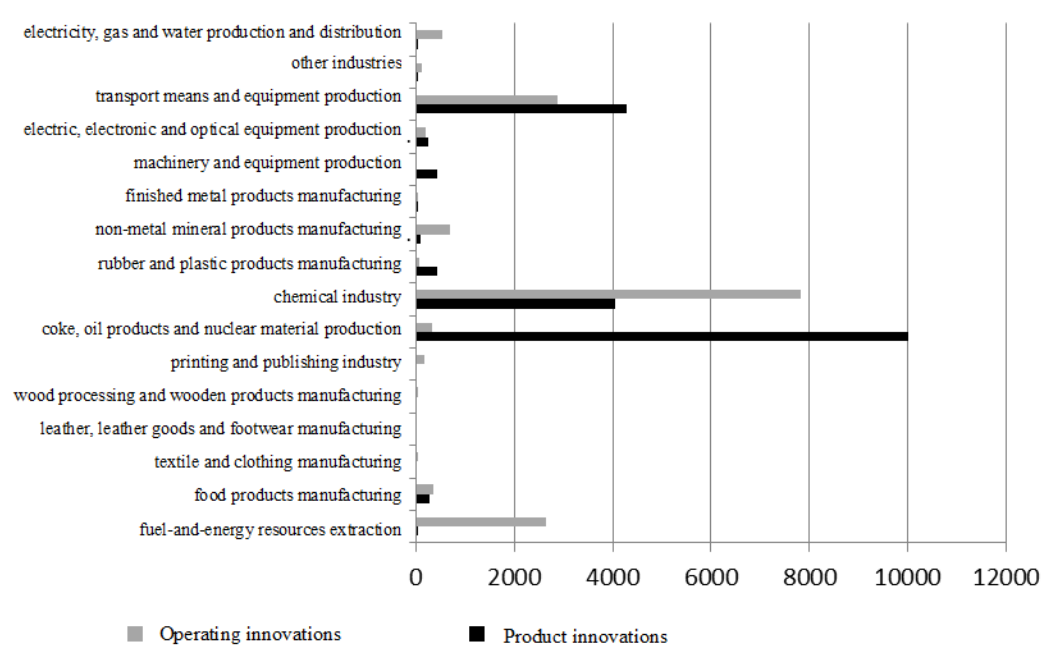

Figure 4. Expenditures of industrial enterprises of Tatarstan according to the type of innovations 2012

Table 3. Dynamics of innovative goods, works and services volume in the Tatarstan Republic

\begin{tabular}{lccccc}
\hline Indicators & 2008 & 2009 & 2010 & 2011 & 2012 \\
\hline $\begin{array}{l}\text { Innovative goods, works and services shipped, mln } \\
\text { rubles } \\
\text { including }\end{array}$ & 132817,1 & 152225,9 & 161216,0 & 195968,9 & 272573,9 \\
$\begin{array}{l}\text { - Innovative goods, works and services by industrial } \\
\text { enterprises }\end{array}$ & 131433,3 & 151944,4 & 160890,1 & 193436,7 & 269306,4 \\
$\begin{array}{l}\text { - Innovative goods, works and services by service } \\
\text { industries }\end{array}$ & 1383,8 & 281,5 & 325,9 & 2532,2 & 3267,5 \\
$\begin{array}{l}\text { Share of shipped innovative production in the total } \\
\text { of shipped own-produced goods, percent }\end{array}$ & 14,8 & 17,9 & 15,6 & 14,9 & 18,4 \\
\hline
\end{tabular}

A peculiar feature of Tatarstan economy is a strong dependence on petrochemical and machine-building complexes which is reflected in innovation activity. A big share of shipped innovative goods and services in the Republic belongs to large enterprises of mineral resources extraction, chemical industry, rubber and plastic goods manufacturing, machinery and equipment production.

Thus, the biggest volume of innovative goods, works and services in 2012 was marked in different economic activities: mineral resources extraction -147621.9 mln rubles (54\%), transport means and equipment production - $53904.3 \mathrm{mln}$ rub. (19.8\%), coke, oil products and nuclear material production $26873.6 \mathrm{mln}$ rub (9.9\%), rubber and plastic goods manufacturing $16581.1 \mathrm{mln}$ rub (6.1\%), chemical industry $15061.3 \mathrm{mln}$ rub (5.5\%) (Tatarstan department of Federal State Statistics Service, 2013).

There was noticed a 3.6 percentage points increase in the share of shipped innovative products in the general volume of the goods shipped by innovatively-active enterprises in 2012 as compared to 2008, which constituted $18.4 \%$ in $2012.38 \%$ of the general volume of shipped goods, works and services is made of the production newly introduced or subjected to significant technological innovations during three years. The share of the production subjected to improvement within three years is $62 \%$ in the general volume of innovative production.

Tatarstan Republic is one of the most active participants of the innovation process among the regions of Volga Federal District. VFD regions can be divided into three groups according to the level of aggregate innovation activity (proportion of the quantity of organizations practicing innovations to the general number of examined organizations). The first group is the leading regions: Mordovia Republic (31.1\%), Chuvash Republic (20.9\%), 
Tatarstan Republic (19.1\%), Nizhny Novgorod region (14.7\%), Perm Territory (14.1\%). The second group: Bashkortostan Republic (13.1\%), Udmurt Republic (13\%), Orenburg region (12.7\%), Penza region (11,4\%), Mariy El Republic (10.6\%). The third group - the rest regions of the District, the level of innovation activity of which varies from $8.7 \%$ (Kirov region) to $6.3 \%$ (Ulyanovsk region), Figure 5.

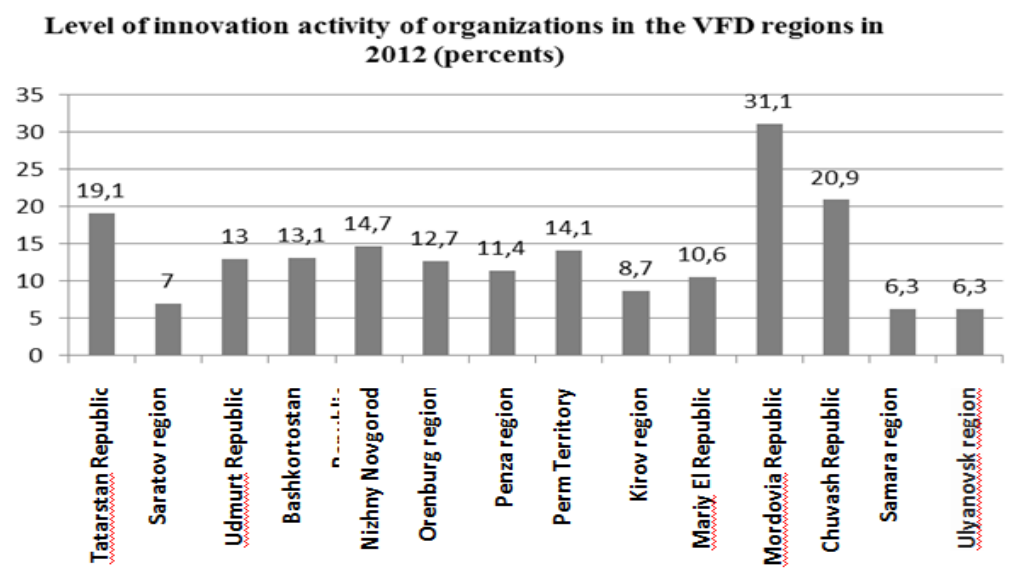

Figure 5. Level of innovation activity of organizations in Volga Federal District

Tatarstan Rebublic occupied the first place in the volume of its own shipped innovative production in 2012 (269306.47 mln rubles) leaving Samara region behind (224855.9 mln rubles), Figure 6.

Tatarstan occupies the fourth place among the VFD regions in the proportion of innovative production in the general volume of production shipped by innovatively-active enterprises $(19.5 \%)$. The first place is taken by Samara region $(24.6 \%)$, the second one - by the Mordovia Republic $(23.8 \%)$ and the third - by the Chuvash Republic (23.1\%). Tatarstan occupies the third place in the volume of investments into technological innovations, which constituted $38101 \mathrm{mln}$ rubles. The first and the second places are occupied by Samara region (74095.1 mln rubles) and Nizhny Novgorod region (59006.8 mln rubles) correspondingly.

\section{Volume of innovative production shipped by industrial enterprises in} VFD regions in 2012 (mln rubles)

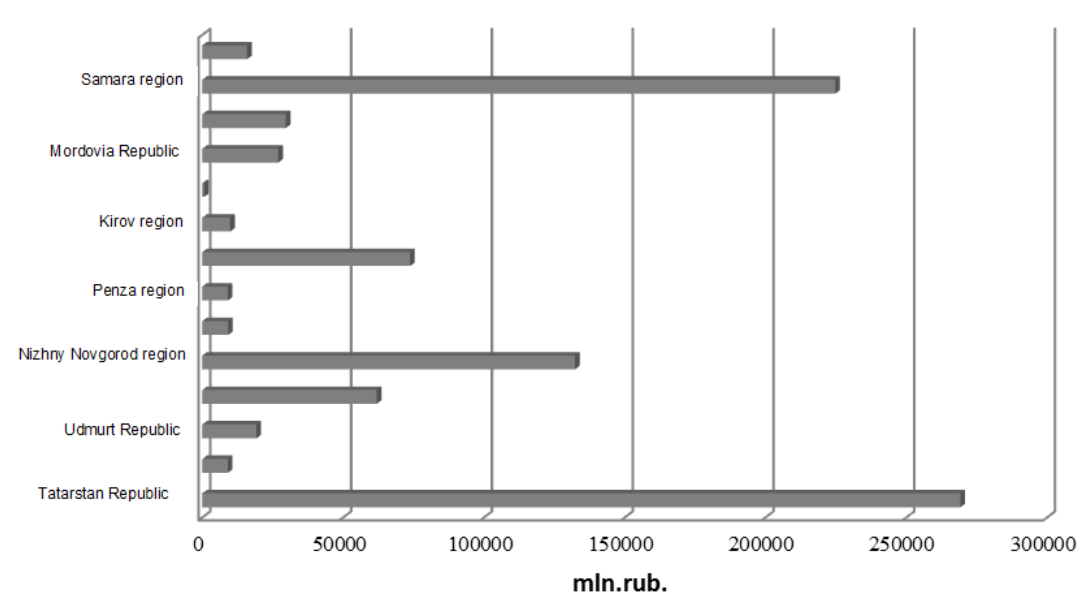

Figure 6. Volume of innovative production shipped by industrial enterprises in VFD regions in 2012 (mln rubles)

The analysis of statistical data in the sphere of innovation activity of the Republic of Tatarstan allows the authors to draw the conclusion that Tatarstan Republic has a significant innovation potential. At present the task set is to stimulate and support the innovation economic sector. Innovation activity of enterprises and organizations is largely determined by the measures of state policy directed not only onto the direct financial support but also 
onto the formation of institutions and mechanisms for the state support of the innovation activity. The development of regulatory framework in the sphere of innovations, development of innovation-oriented structures will allow to form a highly effective system of state regulations of innovations on the regional level.

\section{References}

Development of innovations in Tatarstan as the basis for competition and prosperity in global economy. Retrieved June 17, 2010, from http://www.gosman.ru/conten/Tatarstan_Innovation

Federal State Statistics Service. Retrieved from http://www.gks.ru

Golitchenko, O. (2010). Modernization and reformation of innovation strategy of Russia: problems and solutions. Economic Issues, 8, 41-53.

Gretchenko, A. A. (2011). Formation of national innovative system of Russia - strategic priority of economic development: Problems of modern economy. Euro-Asian international scientific journal, 2, 16-20.

Innovation Development Strategy for Russian Federation to 2020. RF Governmental Decree from 82011 (№ 2227).

Krasnova, O. M. (2009). Innovation activity in Tatarstan Republic in 2009. Economic News of Tatarstan, 4, $100-110$.

Makarova, E. C. (2011). Complex assessment of innovation potential of the region. Economic news of Tatarstan, $4,44-50$.

OECD reviews on innovation policy: Russian Federation. Retrieved from http://gtmarket.ru/new/state

Republic of Tatarstan 2011-2013 Innovation Memorandum: Tatarstan Republic. Cabinet of Ministers' Decree, 24.01.2011 (№ 28)

Sceince and Engineening Indication. (2010, Appendix Tables 6-18, Two volumes). Arington. VA: National Science Foundation.

Socio-economic development of Volga Federal District to 2020. RF Governmental Edict 7.2.2011 (№ 165).

Tatarstan department of Federal State Statistics Service. (2013). Science and innovations in Tatarstan 2013. Statistical Data (p. 95).

\section{Copyrights}

Copyright for this article is retained by the author(s), with first publication rights granted to the journal.

This is an open-access article distributed under the terms and conditions of the Creative Commons Attribution license (http://creativecommons.org/licenses/by/3.0/). 